\title{
Effect of folic acid by mouth on cerebrospinal fluid homovanillic acid and 5-hydroxyindoleacetic acid concentration
}

\author{
RICHARD HUNTER, JOANNA BARNES, G. CURZON, B. D. KANTAMANENI, AND \\ CATHERINE DUNCAN
}

From Friern Hospital, London, the Institute of Neurology, Queen Square, London, and the Medical Research Council Statistical Research and Services Unit, London

SUMMARY Administration of $30 \mathrm{mg}$ folic acid by mouth caused a significant fall in cerebrospinal fluid homovanillic acid concentration in 11 subjects. There was no significant change of 5-hydroxyindoleacetic acid concentration. The fall was less marked in five patients on anticonvulsant medication and failed to reach statistical significance. Neither homovanillic acid nor 5-hydroxyindoleacetic acid concentrations changed significantly when $15 \mathrm{mg}$ folic acid was given in divided dosage for one, two, and four weeks. The effect appeared to be related to the height of serum-folate levels reached and to be independent of cerebrospinal fluid-folate levels, which did not change significantly. Possible mechanisms and their potential therapeutic application are discussed.

It has been reported that folic acid given by mouth in pharmacological doses may cause nervous and gastrointestinal symptoms in some healthy subjects (Hunter, Barnes, Oakeley, and Matthews, 1970). It was suggested that this effect resulted from high tissue levels of folate interfering with brain-amine metabolism for which a reduced folic acid derivative is known to be a cofactor (Blakley, 1969). We therefore investigated the effect of folic acid on cerebrospinal fluid (CSF) homovanillic acid (HVA), and 5-hydroxyindoleacetic acid (5-HIAA) levels, since there is evidence that these provide a measure of turnover of the amines dopamine and 5-hydroxytryptamine in the brain (Bowers and Gerbode, 1968; Guldberg, 1969).

\section{METHODS}

Volunteers were informal patients in a psychiatric hospital and were capable of informed consent. Thirtyfour participated, 29 men and five women. Their ages ranged from 25 to 64 years with a mean of 44 . All were ambulant and on full diet. Apart from five epileptic patients on an anticonvulsant regime of phenobarbitone and phenytoin, subjects required no drugs other than occasional hypnotics. Preliminary examination of peripheral blood and serum-vitamin- $B_{12}$ levels gave results within the normal range.

All lumbar punctures were performed at the same time two hours after breakfast under local anaesthesia with subjects in the lateral recumbent position and premedicated two hours before with $300 \mathrm{mg}$ amylobarbitone sodium. Blood was taken simultaneously for serumfolate estimation. Minimum interval between punctures was two weeks.

Serum- and CSF-folate was estimated by the method of Waters and Mollin (1961) using Lactobacillus casei. CSF HVA was determined by a modified combination of the methods of Andén, Roos, and Werdinius (1963) and Murphy, Robinson, and Sharman (1969) described previously (Curzon, Godwin-Austen, Tomlinson, and Kantamaneni, 1970), and 5-HIAA by a modification of the procedure of Korf and Valkenburgh-Sikkema (1969).

After initial estimation of CSF HVA and 5-HIAA and serum- and CSF-folate, subjects were divided into six groups. In group 1 (11 subjects) and group 2 (five epileptics) repeat estimations were made two weeks later and four hours after a single oral dose of $30 \mathrm{mg}$ folic acid. Group $3(n=6)$ acted as controls and estimations were repeated after two weeks without prior administration of folic acid. In group 4 ( $n=6$ of whom four had also participated in group 1$)$, group five $(n=5)$, and group six $(n=5)$ estimations were repeated after they had received $15 \mathrm{mg}$ folic acid daily in divided dosage for one, two, and four weeks respectively.

RESULTS

Before folic acid mean CSF HVA concentration for 
all subjects $(\mathrm{n}=34)$ was $0.023 \pm \mathrm{SE} 0.002 \mu \mathrm{g} / \mathrm{ml}$. This value was intermediate between those previously established in this laboratory for a group of 11 patients with miscellaneous neurological disorders of $0.039 \pm$ SE $0.004 \mu \mathrm{g} / \mathrm{ml}$, , and of $0.016 \pm \mathrm{SE}$ $0.005 \mu \mathrm{g} / \mathrm{ml}$. for 16 patients with Parkinsonism. It was significantly lower than the mean of patients with miscellaneous neurological disorders $(P<$ 0.001 ) but did not differ significantly from that of the Parkinsonism group.

Mean CSF 5-HIAA concentration before folic acid $(\mathrm{n}=31)$ was $0.018 \pm \mathrm{SE} 0.001 \mu \mathrm{g} / \mathrm{ml}$. This did not differ significantly either from the mean of patients with miscellaneous neurological disorders $(\mathrm{n}=11)$ of $0.023 \pm \mathrm{SE} 0.003 \mu \mathrm{g} / \mathrm{ml}$. or that of patients with Parkinsonism $(n=18)$ of $0.021 \pm$ SE $0.003 \mu \mathrm{g} / \mathrm{ml}$.

GROUP 1 In nine of the 11 subjects HVA levels fell after folic acid, in seven to less than half their original value (Table 1 and Fig. 1); and mean HVA concentration fell significantly $(P<0.001)$. In the eight subjects in whom the estimation was performed mean 5-HIAA concentration also fell but not significantly (Table 2 and Fig. 1). There was also a significant fall in HVA:5-HIAA ratio from 1.51 to $0.82(P<0.05)$.

Serum-folate rose substantially but CSF-folate remained unchanged in eight subjects in whom this estimation was done (Table 1).

GROUP 2 Mean HVA and 5-HIAA concentrations

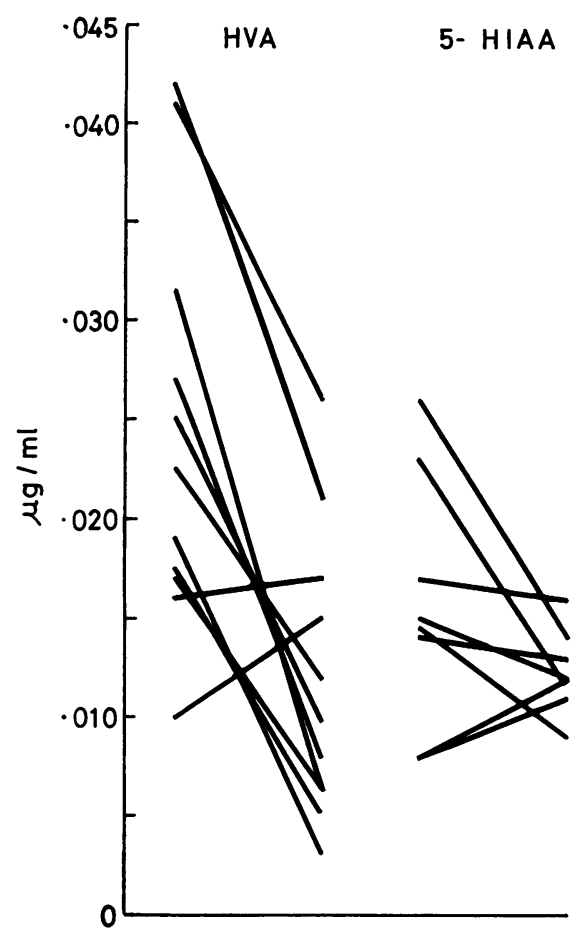

FIG. 1. CSF HVA $(n=11)$ and 5-HIAA $(n=8)$ befor and after $30 \mathrm{mg}$ folic acid by mouth.

TABLE 1

EFFECT OF SINGLE DOSE OF 30 MG FOLIC ACID ON CSF HVA CONCENTRATION AND ON SERUM- AND CSF-FOLATE

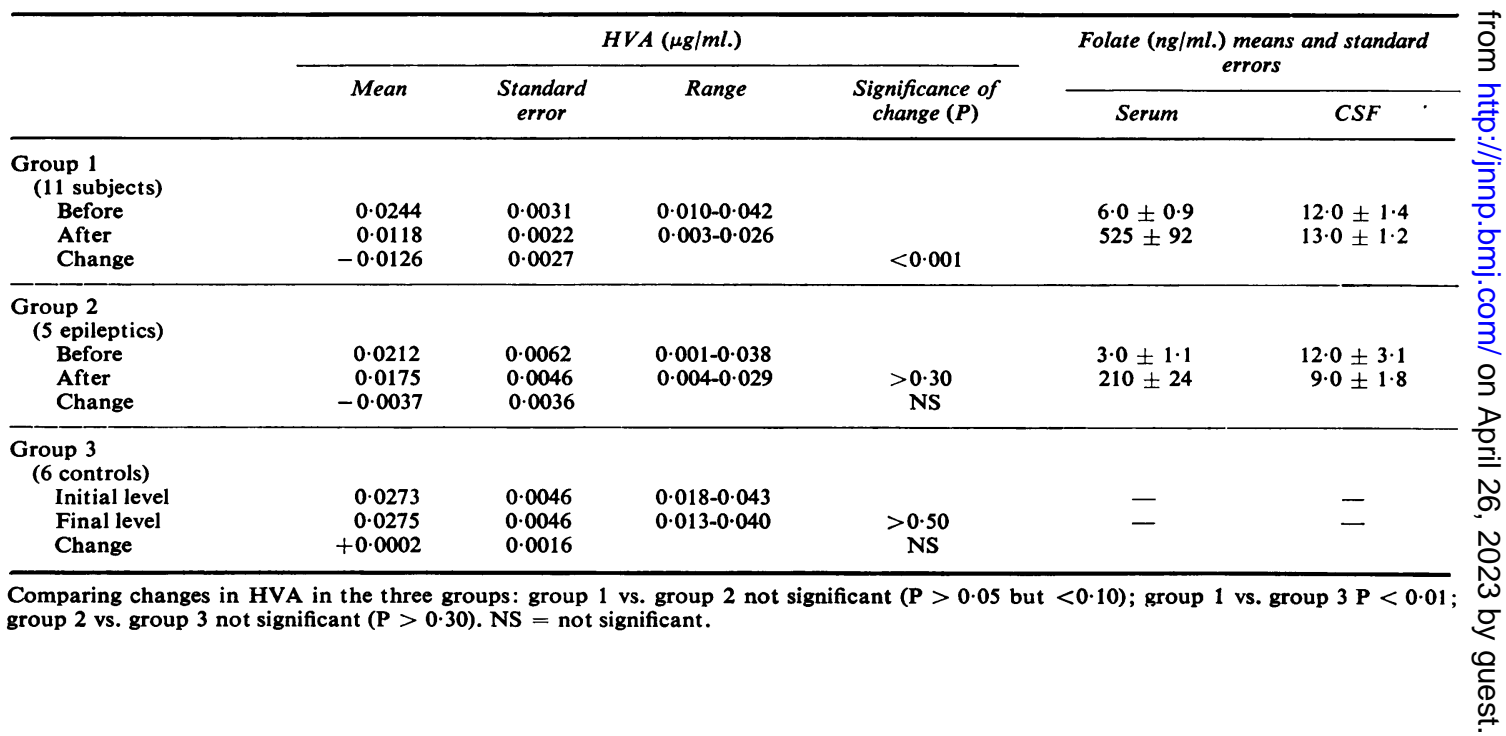


TABLE 2

EFFECT OF SINGLE DOSE OF 30 MG FOLIC ACID ON CSF 5-HIAA LEVELS

\begin{tabular}{|c|c|c|c|c|}
\hline & \multicolumn{4}{|c|}{ 5-HIAA $(\mu \mathrm{g} / \mathrm{ml})}$. \\
\hline & Mean & $\begin{array}{l}\text { Standard } \\
\text { error }\end{array}$ & Range & $\begin{array}{c}\text { Significance } \\
\text { of change }(P)\end{array}$ \\
\hline $\begin{array}{l}\text { Group } 1 \\
\text { (8 subjects) } \\
\text { Before } \\
\text { After } \\
\text { Change }\end{array}$ & $\begin{array}{r}0.0155 \\
0.0123 \\
-0.0032\end{array}$ & $\begin{array}{l}0.0023 \\
0.0007 \\
0.0021\end{array}$ & $\begin{array}{l}0.008-0.026 \\
0.009-0.016\end{array}$ & $\begin{array}{c}>0 \cdot 10 \\
\mathrm{NS}\end{array}$ \\
\hline $\begin{array}{l}\text { Group } 2 \\
\text { (5 epileptics) } \\
\text { Before } \\
\text { After } \\
\text { Change }\end{array}$ & $\begin{array}{r}0.0214 \\
0.0195 \\
-0.0019\end{array}$ & $\begin{array}{l}0.0035 \\
0.0032 \\
0.0027\end{array}$ & $\begin{array}{l}0.014-0.033 \\
0.009-0.026\end{array}$ & $\begin{array}{c}>0.50 \\
\text { NS }\end{array}$ \\
\hline $\begin{array}{l}\text { Group } 3 \\
\text { (6 controls) } \\
\text { Initial level } \\
\text { Final level } \\
\text { Change }\end{array}$ & $\begin{array}{r}0.0205 \\
0.0190 \\
-0.0015\end{array}$ & $\begin{array}{l}0.0025 \\
0.0026 \\
0.0012\end{array}$ & $\begin{array}{l}0.012-0.027 \\
0.011-0.028\end{array}$ & $\begin{array}{c}>0.20 \\
\text { NS }\end{array}$ \\
\hline
\end{tabular}

The three groups did not differ significantly from each other.

before and after $30 \mathrm{mg}$ folic acid in five epileptic patients are given in Tables 1 and 2. The changes were not significant. The rise in serum-folate was much smaller than in subjects in group 1 .

GROUP 3 Mean HVA and 5-HIAA concentrations estimated at an interval of two weeks in six control subjects showed no change (Tables 1 and 2).

COMPARISON OF RESULTS IN GROUPS 1-3 These are shown in Fig. 2. In group 1 mean HVA fell signi-

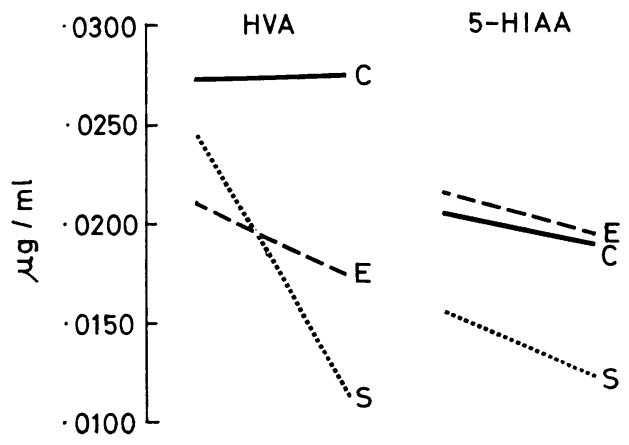

FIG. 2. Mean CSF HVA and 5-HIAA levels before and after $30 \mathrm{mg}$ folic acid by mouth.

$$
\begin{aligned}
& \mathrm{S}=11 \text { subjects }(\mathrm{HVA} 11 ; 5-\mathrm{HIAA} 8) \\
& \mathrm{E}=5 \text { epileptics } \mathrm{C}=6 \text { controls }
\end{aligned}
$$

ficantly compared with controls $(P<0.01)$. The smaller fall of HVA observed in epileptic patients on anticonvulsants (group 2) did not differ significantly from either of the other groups.

GROUPS 4, 5 AND 6 Results of mean HVA, 5-HIAA and serum- and CSF-folate concentrations before and after $15 \mathrm{mg}$ folic acid daily for one, two and four weeks are given in Table 3 . There were no significant changes of HVA or 5-HIAA concentrations.

DISCUSSION

It was found that a single dose of $30 \mathrm{mg}$ folic acid by mouth can significantly lower CSF HVA concen-

TABLE 3

EFFECT OF 15 MG FOLIC ACID FOR ONE, TWO, AND FOUR WEEKS ON CSF HVA AND 5-HIAA LEVELS AND SERUM- AND CSF-FOLATE

\begin{tabular}{|c|c|c|c|c|c|c|c|c|}
\hline & \multicolumn{3}{|c|}{$H V A(\mu g / m l)}$. & \multicolumn{3}{|c|}{ S-HIAA $(\mu \mathrm{g} / \mathrm{ml})}$. & \multicolumn{2}{|c|}{$\begin{array}{c}\text { Folate }(n g / m l) \text { means and } \\
\text { standard errors }\end{array}$} \\
\hline & Mean & $\begin{array}{l}\text { Standard } \\
\text { error }\end{array}$ & Range & Mean & $\begin{array}{l}\text { Standard } \\
\quad \text { error }\end{array}$ & Range & Serum & CSF \\
\hline $\begin{array}{l}\text { One week }(n=6) \\
\text { Before } \\
\text { After } \\
\text { Change }\end{array}$ & $\begin{array}{r}0.0202 \\
0.0198 \\
-0.0004\end{array}$ & $\begin{array}{l}0.0027 \\
0.0049 \\
0.0042\end{array}$ & $\begin{array}{l}0.015-0.031 \\
0.005-0.036\end{array}$ & $\begin{array}{r}0.0193 \\
0.0172 \\
-0.0021\end{array}$ & $\begin{array}{l}0.0020 \\
0.0019 \\
0.0027\end{array}$ & $\begin{array}{l}0.014-0.026 \\
0.010-0.023\end{array}$ & - & - \\
\hline $\begin{array}{l}\text { Two weeks }(n=5) \\
\text { Before } \\
\text { After } \\
\text { Change }\end{array}$ & $\begin{array}{r}0.0139 \\
0.0208 \\
-0.0068 \\
\end{array}$ & $\begin{array}{l}0.0017 \\
0.0029 \\
0 .(043\end{array}$ & $\begin{array}{l}0.008-0.017 \\
0.011-0.029\end{array}$ & $\begin{array}{r}0.0202 \\
0.0177 \\
-0.0025\end{array}$ & $\begin{array}{l}0.0041 \\
0.0017 \\
0.0056\end{array}$ & $\begin{array}{l}0.014-0.036 \\
0.012-0.021\end{array}$ & $\begin{array}{l}4 \cdot 0 \pm 1 \cdot 0 \\
173 \pm 35\end{array}$ & $\begin{array}{l}9 \cdot 5 \pm 1 \cdot 6 \\
12 \cdot 0 \pm 2 \cdot 1\end{array}$ \\
\hline $\begin{array}{l}\text { Four weeks }(n=5) \\
\text { Before } \\
\text { After } \\
\text { Change }\end{array}$ & $\begin{array}{r}0.0245 \\
0.0248 \\
+0.0003\end{array}$ & $\begin{array}{l}0.0067 \\
0.0050 \\
0.0057\end{array}$ & $\begin{array}{l}0.009-0 \cdot 040 \\
0 \cdot 010-0 \cdot 040\end{array}$ & $\begin{array}{r}0.0160 \\
0.0201 \\
+0.0050\end{array}$ & $\begin{array}{l}0.0035 \\
0.0047 \\
0.0066\end{array}$ & $\begin{array}{l}0.001-0.024 \\
0 \cdot 006-0 \cdot 030\end{array}$ & $\begin{aligned} 5 \cdot 0 & \pm 1 \cdot 2 \\
35 & \pm 12\end{aligned}$ & $\begin{array}{l}10 \cdot 5 \pm 1 \cdot 4 \\
14 \cdot 0 \pm 2 \cdot 4\end{array}$ \\
\hline
\end{tabular}
LEVELS

None of the above changes were significant. 
tration and so by implication affect the metabolism in the brain of its precursor dopamine. The alternative possibility that folate affects transport of HVA either from brain to CSF or from CSF to blood is not excluded.

Epileptic patients showed only a small fall of HVA which was not significant. Presumably this was related to the much smaller rise of serum-folate observed in them than in the other subjects given $30 \mathrm{mg}$ folic acid who were not on an anticonvulsant regime. Such drugs are known to interfere with the absorption of folate from the gut (Chanarin, 1969; Benn, Swan, Cooke, Blair, Matty, and Smith, 1971).

In groups 4, 5, and 6 administration of $15 \mathrm{mg}$ folic acid daily in divided dosage for one, two, and four weeks respectively did not cause a significant change of HVA or 5-HIAA concentrations. This lack of effect correlated with still smaller increments of serum-folate in groups 5 and 6 for whom results are available than that observed in epileptic patients given a single $30 \mathrm{mg}$ dose.

Mean HVA concentration for all subjects in this series taken together before administration of folic acid was significantly lower than that of a group of patients with miscellaneous neurological conditions already referred to and approximated that of a group of patients with Parkinsonism. This may reflect the high incidence of extrapyramidal disorders (Jones and Hunter, 1969) and cerebral atrophic conditions (Hunter, Jones, and Cooper, 1968) found in patients with persistent or disabling mental symptoms. Conceivably differences in procedures for taking CSF may also have played a part, since the three series of patients were examined in different hospitals.

One possible mechanism for the effect of folic acid on CSF HVA levels is suggested by the in vitro requirement of 5,6,7,8-tetrahydrofolic acid as a cofactor for catecholamine (Kaufman, 1963; Nagatsu, Levitt, and Udenfriend, 1964) and 5hydroxytryptamine (Gal, Armstrong, and Ginsberg, 1966) synthesis. This cofactor may be formed by reduction of 7,8-dihydrofolic acid through the action of dihydrofolic acid reductase. Folic acid is a competitive inhibitor of this enzyme (Bertino, Perkins, and Johns, 1965), though its action is much weaker than that of folate analogues in clinical use. Blair (1970) therefore suggested that large doses of folic acid giving high tissue levels may have toxic effects by interfering with cofactor synthesis. Such inhibition of dihydrofolic acid reductase has been demonstrated in vivo by Auletta, Mead, and Waravdekar (1970) who found that when mice were injected with $300 \mathrm{mg}$ folic acid per kilogram body weight their kidney dihydrofolic acid reductase activity fell by $80 \%$ within 10 minutes and that low activity persisted for 72 hours. Clearly a similar inhibition may also lead to reduced dopamine synthesis and hence decreased formation of its metabolite HVA.

The decrease of CSF HVA after a single dose of $30 \mathrm{mg}$ folic acid does not explain the toxic or alerting effects of daily administration of $15 \mathrm{mg}$ folic acid, since in the present investigation this dose was not associated with HVA change. Increased dopamine turnover after L-dopa administration may cause alerting (Blaschko and Chrusciel, 1960) but also increases CSF HVA (Curzon et al., 1970). However, HVA formation requires two enzymes (Axelrod, 1966), the intraneuronal $\overparen{\odot}$ monoamine oxidase and the extraneuronal $\cong$ catecholamine-O-methyl transferase. Impaired क extraneuronal metabolism of dopamine in the $\overrightarrow{0}$ presence of normal neuronal release would lead $\vec{\overrightarrow{ }}$ to increased dopamine effect at receptor sites and $\vec{\omega}$ low CSF HVA concentration. In these circumstances alerting might occur. Such a mechanism would be consistent with folic acid causing a fall of HVA $\omega$ without a significant effect on 5-HIAA levels since, although both catecholamine and 5-hydroxy or tryptamine synthesis require tetrahydrofolic acio $\mathrm{O}$-methyl transferase is involved in catecholamin metabolism only.

If this explanation is correct, it implies a possib effect of folic acid supplement on dyskinetic syrg dromes. Parkinsonism is associated with decrease brain dopamine synthesis (Hornykiewicz, 1963) and one suggested mechanism of Huntington's chorea increased sensitivity of dopamine receptors (Klawans, Paulson, and Barbeau, 1970). Therefore if folic acid impairs dopamine synthesis, its administration might be expected to exacerbate Parkinsonism and possibly have a beneficial effect on the manifestations of Huntington's chorea. The opposite effects should occur if the low HVA levels caused by folic $\overrightarrow{\vec{P}}$ acid are due to impaired extraneuronal dopamine destruction.

Folic acid administration has occasionally been reported to cause fits in patients with megaloblastic anaemia due either to anticonvulsant medication (Chanarin, Laidlaw, Loughridge, and Mollin, 1960; Reynolds, Chanarin, and Matthews, 1968) or folate absorption defect (Lanzkowsky et al., 1969). There has been no satisfactory explanation of this rare complication (Richens, 1971). Folic acid has also been observed to cause convulsions in rats when given by intraventricular injection in a dose of $2 \cdot 2 \mu \mathrm{g} \frac{7}{0}$ (Noell, Magoss, Cohen, Holland, and Walters, 1960). Generalized synchronous spikes were recorded $N$ within 10 minutes followed by 'cortical seizures' lasting several hours.

It may be that subjects with low dihydrofolic acid 
reductase levels are predisposed to a toxic response to exogenous folic acid and increased fit frequency may be a manifestation of such sensitivity. If this is so then administration of the reduced form of folic acid, 5-methylhydrotetrafolic acid, or other folate derivative may not have toxic effects and seems worthy of clinical trial.

We thank Dr. J. A. Blair of the department of chemistry, University of Aston in Birmingham, for helpful discussion and Dr. B. A. L. Hurn of the Wellcome Research Laboratories, Beckenham, Kent, for the folate estimations. The Clinical Research Fund of the Department of Health supported B.D.K.

\section{REFERENCES}

Andén, N.-E., Roos, B.-E., and Werdinius, B. (1963). On the occurrence of homovanillic acid in brain and cerebrospinal fluid and its determination by a fluorometric method. Life Sci., 2, 448-458.

Auletta, A., Mead, J. A. R., and Waravdekar, V. S. (1970). The effect of folate and homofolate on dihydrofolate reductase levels in mouse kidney. (Abstract.) Fed. Proc., 29, 610.

Axelrod, J. (1966). Methylation reactions in the formation and metabolism of catecholamines and other biogenic amines. Pharmacol. Rev., 18, 95-113.

Benn, A., Swan, C. H. J., Cooke, W. T., Blair, J. A., Matty, A. J., and Smith, M. E. (1971). Effect of intraluminal pH on the absorption of pteroylmonoglutamic acid. Brit. med.J., 1, 148-150.

Bertino, J. R., Perkins, J. P., and Johns, D. G. (1965). Purification and properties of dihydrofolate reductase from Ehrlich ascites carcinoma cells. Biochemistry, 4, 839-846.

Blair, J. A. (1970). Toxicity of folic acid. Lancet, 1, 360.

Blakley, R. L. (1969). The Biochemistry of Folic Acid and Related Pteridines, p. 293. North-Holland: Amsterdam.

Blaschko, H., and Chrusciel, T. L. (1960). The decarboxylation of amino acids related to tyrosine and their awakening action in reserpine-treated mice. J. Physiol. (Lond.), 151, 272-284.

Bowers, M. B., Jr., and Gerbode, F. (1968). CSF 5HIAA: Effects of probenecid and parachlorophenylalanine. Life Sci., 7, 773-776.

Chanarin, I. (1969). The Megaloblastic Anaemias, p. 830. Blackwell: Oxford.

Chanarin, I., Laidlaw, J., Loughridge, L. W., and Mollin, D. L. (1960). Megaloblastic anaemia due to phenobarbitone; the convulsant action of therapeutic doses of folic acid. Brit. med. J., 1, 1099-1102.

Curzon, G., Godwin-Austen, R. B., Tomlinson, E. B., and Kantamaneni, B. D. (1970). The cerebrospinal fluid homovanillic acid concentration in patients with Parkin- sonism treated with L-dopa. J. Neurol. Neurosurg. Psychiat., 33, 1-6.

Gal, E. M., Armstrong, J. C., and Ginsberg, B. (1966). The nature of in vitro hydroxylation of L-tryptophan by brain tissue. J. Neurochem., 13, 643-654.

Guldberg, H. C. (1969). Changes in amine metabolite concentrations in cerebrospinal fluid as an index of turnover. Pp. 55-64 in Metabolism of Amines in the Brain. Edited by G. Hooper. Macmillan: London.

Hornykiewicz, O. (1963). Die topische Lokalisation und das Verhalten von Noradrenalin und Dopamin (3-Hydroxytyramin) in der Substantia nigra des normalen und Parkinson-kranken Menschen. Wien. klin. Wschr., 75, 309-312.

Hunter, R., Barnes, J., Oakeley, H. F., and Matthews, D. M. (1970). Toxicity of folic acid given in pharmacological doses to healthy volunteers. Lancet, 1, 61-63.

Hunter, R., Jones, M., and Cooper, F. (1968). Modified lumbar air encephalography in the investigation of longstay psychiatric patients. J. neurol. Sci., 6, 593-596.

Jones, M., and Hunter, R. (1969). Abnormal movements in patients with chronic psychiatric illness, pp. 53-59. In Psychotropic Drugs and Dysfunctions of the Basal Ganglia. Edited by G. E. Crane, and R. Gardner, Jr. Public Health Service Publicat:o.1 No. 1938: Washington, U.S.A.

Kaufman, S. (1963). Phenylalanine hydroxylation, pp. 373383. In The Enzymes. Edited by P. D. Boyer, H. Lardy, and K. Myrbäck. Vol. 8, 2nd edn. Academic Press: New York.

Klawans, H. C., Paulson, G. W., and Barbeau, A. (1970). Predictive test for Huntington's chorea. Lancet, 2, 11851186.

Korf, J., and Valkenburgh-Sikkema, T. (1969). Fluorometric determination of 5-hydroxyindoleacetic acid in human urine and cerebrospinal fluid. Clin. chim. Acta, 26, 301-306.

Lanzkowsky, P., Erlandson, M. E., and Bezan, A. I. (1969). Isolated defect of folic acid absorption associated with mental retardation and cerebral calcification. Blood, 34, 452-465.

Murphy, G. F., Robinson, D., and Sharman, D. F. (1969). The effect of tropolone on the formation of 3,4-dihydroxyphenylacetic acid and 4-hydroxy-3-methoxyphenylacetic acid in the brain of the mouse. Brit. J. Pharmacol., 36, 107-115.

Nagatsu, T., Levitt, M., and Udenfriend, S. (1964). Tyrosine hydroxylase. The initial step in norepinephrine biosynthesis. J. biol. Chem., 239, 2910-2917.

Noell, W. K., Magoss, M. S., Cohen, L. H., Holland, J. F., and Walters, G. C. (1960). Cerebral effects of folic acid, pyrimidines, and amino acids and their metabolites. (Abstract.) Electroenceph. clin. Neurophysiol., 12, 238.

Reynolds, E. H., Chanarin, I., and Matthews, D. M. (1968). Neuropsychiatric aspects of anticonvulsant megaloblastic anaemia. Lancet, 1, 394-397.

Richens, A. (1971). Folic acid in epilepsy. Brit. med. J., 1, 109.

Waters, A. H., and Mollin, D. L. (1961). Studies on the folic acid activity of human serum. J. clin. Path., 14, 335-344. 